\title{
From Food Desert to Food Mirage: Race, Social Class, and Food Shopping in a Gentrifying Neighborhood
}

\author{
Daniel Monroe Sullivan \\ Department of Sociology, Portland State University, Portland, USA \\ Email: dsulliva@pdx.edu
}

Received November $14^{\text {th }}, 2013$; revised December $14^{\text {th }}$, 2013; accepted December $21^{\text {st }}, 2013$

\begin{abstract}
Copyright (c) 2014 Daniel Monroe Sullivan. This is an open access article distributed under the Creative Commons Attribution License, which permits unrestricted use, distribution, and reproduction in any medium, provided the original work is properly cited. In accordance of the Creative Commons Attribution License all Copyrights (C) 2014 are reserved for SCIRP and the owner of the intellectual property Daniel Monroe Sullivan. All Copyright $(\subset) 2014$ are guarded by law and by SCIRP as a guardian.
\end{abstract}

\begin{abstract}
New supermarkets in previous "food deserts" can benefit residents by improving their access to healthful, affordable food. But in gentrifying neighborhoods characterized by the inflow of middle-class, white residents and the outflow of working class, minorities, who benefits from a new supermarket that emphasizes organic food and environmental sustainability? This paper contributes to the food access literature by examining the food shopping behavior of diverse residents by using survey data and probability sampling in the Alberta neighborhood in Portland, Oregon (USA). Regression results show that college-educated (62\%) and white residents (60\%) are much more likely to shop there weekly, regardless of age, gender, owner-renter status, distance from supermarket, or length of time living in the neighborhood. These findings indicate that supermarkets that promote healthy living and environmental sustainability need to be sensitive to the racial "symbolic boundaries" and socioeconomic barriers that may create "food mirages" by limiting food access to poor and minority residents.
\end{abstract}

Keywords: Food Access; Food Desert; Food Mirage; Social Exclusion; Gentrification; Neighborhoods; Race; Social Class

\section{Introduction}

Imagine yourself living in a racially, ethnically, and socioeconomically mixed neighborhood that has been a food desert for the past seven years. Yes, there were supermarkets in surrounding neighborhoods to which you could drive or take public transportation. But there were only small corner stores in your neighborhood, mostly filled with processed, unhealthful food. During those seven years a boarded-up former supermarket with a barbed wire fence surrounding it served as a constant reminder of your food desert condition. Now, fast forward seven years. You walk into a new neighborhood supermarket that replaces the boarded-up one. It has bright-colored walls and art, large windows that let in natural light, a knowledgeable staff, and wide aisles filled with fresh organic fruit, vegetables, fish, meat, and cheese. There is even a place for you to sit and enjoy a coffee or sandwich.

Most of us would agree that residents living in neighborhoods with a supermarket have greater food access than those living in neighborhoods without one. Indeed, scholars from a range of countries have documented food deserts in poor neighborhoods (Alwitt \& Donley, 1997; Coveney \& O’Dwyer, 2009; Paez et al., 2010; Sparkes et al., 2011)—including poor and minority neighborhoods in the USA (Morland et al., 2002; Small \& McDermott, 2006; Walker et al., 2010), and the resulting limited availability, lower quality, and higher prices of fruit, vegetables and other healthful food (Wrigley, 2002; White, 2007). Although some studies have found that residents in food deserts are able to find ways of accessing food sufficiently outside their neighborhood (Hallsworth \& Wood, 1986; Guy \& David, 2004; White et al., 2004), it is clear that neighborhoods without supermarkets create an environment that contributes to residents having a variety of health problems including obesity, cardiovascular problems, and certain types of cancer (Larson et al., 2009).

\section{Competing Views of a New Supermarket in a Gentrifying Neighborhood}

Where this agreement usually ends, however, is on the question of how many and what type of neighborhood residents benefit from the new supermarket. Developers, as well as some local politicians, neighborhood leaders and other "urban revitalization/regeneration" advocates (they tend to avoid the term "gentrification”), would certainly interpret the new supermarket as an unequivocal positive change. In fact, it fits neatly within their larger belief that the middle class moving into poor urban neighborhoods is beneficial to all residents-it deconcentrates poverty, increases economic diversity, and creates what they would call urban regeneration, renewal, revitalization, or some other positive term (Grogan, 2000; Byrne, 2003). As Duany (2001, p. 36) states, gentrification is "the rising tide that lifts all boats." Shaw and Porter (2009), commenting on studies of "urban regeneration" strategies in many cities throughout the world, are critical of the near unanimity among advocates and their unwillingness to consider possible negative consequences 
such as how little low-income residents benefit from development activities (but see Pascual-Molinas \& Ribera-Fumaz, 2009).

To be fair, the perspective of development advocates has some validity. In free-market economies, businesses are more likely to open in neighborhoods that have sufficient demand for their products. So higher-income residents moving into poor neighborhoods will provide market signals to prospective businesses that there is now sufficient demand for their products. And there are numerous examples of this happening, including the opening or upscaling of supermarkets (Bridge \& Dowling, 2001; Gonzalez \& Waley, 2012). What is missing from the food access discussion, however, is an analysis of which neighborhood residents shop at the supermarkets and how frequently; proponents are satisfied by the mere existence of these supermarkets and do not investigate the possibility of social exclusion.

Many urban scholars, however, would examine the opening of this supermarket more critically, questioning whether the food desert has truly disappeared or whether the neighborhood has become instead a "food mirage"-i.e., what appears to be adequate neighborhood food access actually obscures social exclusion, with some minority residents and those with less education and income finding the new supermarket to be too expensive or culturally alien (Short et al., 2007; Everett, 2011; Breyer \& Voss-Andreae, 2013). First, many urban scholars would not label the general neighborhood changes using positive terms such as urban regeneration but instead call it gentrification, which Kennedy \& Leonard (2001) define as the process of wealthier residents moving into poorer neighborhoods in sufficient numbers to change its social class composition and neighborhood identity. Second, they would note that researchers have found that most new retail in gentrifying neighborhoods caters to newcomers and outside clientele, who are more likely to be white and have more education and income than longtime residents. They usually support this claim by using one or more of the following strategies: 1 ) describing how the semiotics of the new retail-e.g., products, prices and cultural symbols such as music and signage appeal largely to gentrifiers (Patch, 2008; Zukin, 2008; Zukin et al., 2009), 2) detailing a qualitative account of the typical gentrifier clientele of the new retail (Lloyd, 2006; Zukin, 2008; Zukin et al., 2009), or 3) interviewing a small number of non-randomly selected longtime residents regarding their feelings of social exclusion toward new retail (Freeman, 2006; Maurrasse, 2006; Deener, 2007; Sullivan and Shaw, 2011).

\section{The Study}

I argue that, although these urban scholars' skepticism may be justified when referring to retail that sell non-essential retail goods-e.g., restaurants, bars, and clothing boutiques-it remains unclear whether their skepticism is merited when analyzing retail that sell essential goods like supermarket food. Unlike lattes, tattoos, and hand-made purses, everyone needs food. We need more evidence regarding the extent to which different types of residents in a gentrifying neighborhood benefit from a supermarket opening in a previous food desert.

I also argue that the evidence needs to be collected in a systematic way, using probability sampling and surveying a substantial number of residents. These data will allow researchers to use regression analysis to measure the salience of resident characteristics: e.g., race/ethnicity, social class, and years living in the neighborhood. Like Short et al. (2007) and Breyer \& Voss-Andreae (2013), I also contend that it is vital to understand residents' actual food shopping behavior rather than just the presence of a new supermarket, since their usage will most directly measure how much they benefit from it.

This paper examines resident use of a relatively new supermarket in the Alberta neighborhood in Portland, Oregon, onethat is a racially and socioeconomically mixed, gentrifying, and that did not have a supermarket for a number of years until one opened recently. This study, on the one hand, examines the tacit assumption of the pro-development advocates by examining the actual shopping behavior of residents-429 randomly selected ones using survey data-rather than simply assuming they shop at the new supermarket. It also, on the other hand, contributes to the retail gentrification literature by focusing on essential retail items-food-rather than non-essential ones such as fashion clothes and lattes. The two main research questions are: How frequently do neighborhood residents shop at the new supermarket? And, given the diversity among residents, are there differences in usage based race, social class or other demographic characteristics?

\section{Portland: Example of Environmental Sustainability}

Portland is known nationally and internationally for its progressive planning and environmental sustainability (Svoboda, 2008; Zellmer, 2010). Its regional and city government promote such pro-environmental policies as reducing carbon dioxide emission (Rutland \& Aylett, 2008), recycling, composting, public transportation (Killingsworth \& Lamming, 2001), bicycle commuting (Mirk, 2012), and urban growth boundaries (Jun, 2004). This last feature minimizes urban sprawl and encourages local agriculture. In tandem with local nonprofits, the Portland region has farm-to-school food programs and a substantial number of farmers markets and community- supported agriculture programs (The Diggable City Project Team, 2005). It should come as no surprise that many Portlanders, including newcomers, embrace pro-environmental policies and are attracted to such food-related activities as urban farming and local/region food options. Related to environmental sustainability and healthy food initiatives, a substantial number of residents engage in what Baarts and Pedersen (2009) refer to as "mind-body" practices-i.e., activities that emphasize an awareness of interrelatedness of the mental, emotional, and physical components of well-being such as alternative medicine, yoga, tai chi, meditation, and acupuncture. This set of practices is supported by Portland's large Oregon College of Oriental Medicine and other mind- body training institutions.

\section{The Alberta Neighborhood}

Portland residents who are attracted to environmental sustainability, healthy eating, and mind-body practices are not evenly distributed spatially throughout the city. One of the areas to which they are attracted is the Alberta neighborhood. A person touring through the Alberta neighborhood would immediately notice the large number of bike lanes, community and private vegetable and fruit gardens, chicken coops, and dozens of mind-body businesses.

It should come as no surprise that, as residents attracted to environmental sustainability and mind-body practices have 
moved into the neighborhood, there has been marked gentrification. There has been a large increase in residents with a college degree, professional and managerial occupations, and median household income. There has been a similar increase in house prices and rent. Although difficult to measure, there has also been displacement of longtime residents, many of whom are low-income (Burk, 2006; Schmidt, 2012). This process of gentrification has been accompanied by substantial racial change, with a decline in black residents (from 34\% in 1990 to $14 \%$ in 2010) and an increase in whites (from 57\% to $73 \%$ ). The decline in black residents coincides with a decrease in black businesses and institutions (Beaven, 2005; Fitzgibbon, 2006), although some are managing to maintain their neighborhood presence (Scott, 2012).

\section{The New Supermarket}

This area had been a food desert from 1994 onward when the only supermarket within one mile of its center closed. For seven years, residents had to choose between patronizing the dozens of neighborhood corner stores that sold largely unhealthful food and drink and shopping at a supermarket outside the neighborhood.

Within this context of residential and retail change, including more residents and higher incomes, it is not surprising that a supermarket opened in what had been previously a food desert. And it is not just a standard supermarket. Mirroring the businesses that had already opened in the neighborhood in the near past, the new supermarket sells products and a life-style that promote a mind-body connection. It specializes in organic fruits and vegetables, sustainably harvested fish, non-industrially processed meats, and a wide selection of cheeses, wines and specialty beers. Many of these products are produced locally/ regionally, with signage next to them alerting the customer to their environmental sustainability. It also promotes the mindbody lifestyle by selling such items as BPA-free water bottles, yoga mats, and books promoting such practices as meditation and eating raw food. It sponsors "Health and Wellness" classes that "promote healthy lives and well-being from the inside out." It encourages health and environmental sustainability, in addition, by providing bike racks, recycling bins, a newsstand with free issues of Green Living magazine, and a free drinking water refilling station (to discourage buying disposable plastic water bottles). It even has the dictionary definition of sustainability painted in large letters on its walls.

New Seasons does make an attempt, however, to increase food access to neighborhood residents who do not easily fall into the gentrifier, mind-body category. It sells national brands of breakfast cereals and other common products, uses "Everyday Value" signs to signal which products are more affordable, accepts food stamps and coupons that assist poor women and children, offers discounts to seniors, and donates money to organizations that support minority residents.

The main goal of this study is to examine usage of this new supermarket and, given the neighborhood's racial/ethnic and social class diversity, analyze whether particular types of residents use the store more than others.

\section{Data and Methodology}

A research team documented all occupied housing units in eight census block groups that were close to the New Seasons supermarket. Then vacant houses and institutionalized housing (e.g., drug rehabilitation centers) were eliminated from the sampling frame. 679 housing units were then randomly selected. Surveyors attempted to maximize the response rate using the following practices: sending a postcard in advance explaining the goal of the survey, offering an incentive for participation, going to the selected households at different times of the day and evening and different days of the week, and attempting to make contact up to twelve times. 425 individuals from these households participated in a face-to-face survey, resulting in a $63.2 \%$ response rate. Demographic analysis revealed that participants were similar to neighborhood residents in terms of age, gender, whether they had children living at home, and distance from their household to the supermarket. As is common with neighborhood survey research, whites, homeowners, and those with a college degree were overrepresented in the sample.

The survey was conducted approximately two and a half years after the New Seasons supermarket opened, giving respondents enough time to become aware of its existence and change their food shopping habits, if desired. The dependent variable is ordinal on the survey instrument, measuring the frequency of shopping at New Seasons during the past twelve months: never, less than monthly, at least monthly, and at least weekly. The ordinal variable is used for univariate and bivariate analyses, but a binary of $1=$ at least weekly shopping at New Seasons, $0=$ less than weekly shopping is used for the logistic regression analysis because it most accurately measures whether residents use New Seasons as one of their primary food shopping venues.

The independent variables of theoretical interest are race/ ethnicity, education, tenure status, and years living in the neighborhood. Race/ethnicity is measured using four categories for the initial bivariate analyses: white, non-Latino; black, nonLatino; Latino, and other race/multiracial. Bivariate analysis with the dependent variable, however, reveals that all three non-white categories have similar shopping usage; so, for the sake of parsimony, race/ethnicity is a binary in the logistic regression: 1 = white, non-Latino; 0 = minority. Similarly, education is originally measured in five categories: less than high school degree, high school degree, some college/associate's degree, college degree, and graduate/professional degree. Bivariate analysis with the dependent variable, however, indicates that the three lowest education categories have similar shopping usage at New Seasons and the two highest education categories also have similar usage patterns to each other but distinct from the lower education categories. So, for the sake of parsimony, education is a binary in the logistic regression: 1 = college degree or higher; $0=$ less than college degree. Tenure status is a binary: $1=$ homeowner; $0=$ renter. Years living in the neighborhood is a scale variable. Other independent variables are included as control variables. Gender is binary: 1 = male; $0=$ female. Age and distance from the New Seasons supermarket are scale.

Multicollinearity diagnostics show no collinearity problems with the most parsimonious model presented here. Interaction terms were tested but none were statistically significant and, hence, they were not included in the regression.

\section{Results}

\section{Descriptive Statistics}

Table 1 illustrates the descriptive statistics, including for the whole sample and stratified by race. As is common in gentrify- 


\section{M. SULLIVAN}

ing neighborhoods that are going through racial change, whites are more likely to own their home (69\% v. 55\%) and have a college degree $(62 \%$ v. $21 \%)$. Whites also tend to live slightly closer to the new grocery store (10 blocks v. 11 blocks). Black residents tend to be older (45 years old v. 40 years) and have lived longer in the neighborhood (12 years v. 7 years).

The vast majority of residents (90\%) have shopped at least once at the new supermarket during the past twelve months, but with varying levels of frequency. Fifteen percent shop there less than monthly, 25\% shop there at least monthly but less than weekly and about $50 \%$ shop there at least weekly. This last category-shopping there at least weekly_suggests that these residents use the new store as one of their main food shopping venues.

\section{The Importance of Race}

Table 1 also illustrates the usage of the new supermarket by race. Supporting the race hypothesis at the bi-variate level, white residents are nearly three times as likely to shop at least weekly at the new supermarket as non-whites. There is some variation among racial minorities-black residents (15\%) are less likely than "other race/multiracial" (33\%) and Latinos (38\%) - but white weekly usage clearly surpasses all of these minority groups. On the other extreme, non-whites are nearly four times as likely to never have shopped there within the last twelve months.

Given that race is correlated with three other important dimensions of living in gentrifying neighborhoods that are undergoing racial change-whites are more likely to be homeowners, college educated, and newcomers-I use regression analysis to examine if race has an independent and nonspurious effect on shopping behavior. Logistic regression results from Table 2 further support the race hypothesis. In this racially diverse neighborhood, the odds that a white resident shops there weekly are over 3.5 times as likely as non-whites, after controlling for variables that are directly related to gentrification: social class, tenure status, and years living in the neighborhood. These findings support qualitative gentrification research that have found race/ethnicity to be an important factor in understanding social exclusion in regards to retail venues, which researchers suggest is due in part to potential shoppers perceiving racialized symbolic boundaries (Maly, 2005; Deener, 2007; Patch, 2008; Zukin et al., 2009; Sullivan \& Shaw, 2011).

Table 1.

Descriptive statistics of variables, stratified by race.

\begin{tabular}{|c|c|c|c|}
\hline & Overall Mean & Whites & Non-whites \\
\hline \multicolumn{4}{|c|}{ Dependent Variables } \\
\hline Shop at New Supermarket at Least Weekly & $49.9 \%^{* *}$ & $60.3 \%$ & $21.2 \%$ \\
\hline Shop at New Supermarket at Least Monthly & $74.4 \%^{* *}$ & $84.3 \%$ & $46.9 \%$ \\
\hline Shop at New Supermarket at Least Yearly & $89.2 \%^{* *}$ & $93.9 \%$ & $76.1 \%$ \\
\hline Never Shop at New Supermarket & $10.8 \%^{* *}$ & $6.1 \%$ & $23.9 \%$ \\
\hline \multicolumn{4}{|c|}{ Independent Variables } \\
\hline College Degree & $50.8 \%^{* *}$ & $61.6 \%$ & $21.2 \%$ \\
\hline Homeowner & $65.2 \%^{* *}$ & $68.9 \%$ & $54.9 \%$ \\
\hline Years Living in the Neighborhood & $8.5^{* *}$ & 7.4 & 11.7 \\
\hline Age & $41.5^{* *}$ & 40.1 & 45.4 \\
\hline Gender (Male) & $42.1 \%$ & $44.6 \%$ & $35.4 \%$ \\
\hline Distance to New Supermarket (blocks) & $10.0^{* *}$ & 9.6 & 11.3 \\
\hline $\mathrm{N}$ & 425 & 312 & 113 \\
\hline
\end{tabular}

Note: Chi-square test of proportional differences. ${ }^{*}=p<0.05 ;{ }^{* *}=p<0.01$.

Table 2.

Logistic regression results factors influencing weekly use of new supermarket.

\begin{tabular}{|c|c|c|c|}
\hline & B & Significance & Standard error \\
\hline Race (Whites) & 1.265 & ** & 0.281 \\
\hline College degree & 1.159 & ** & 0.242 \\
\hline Homeowner (reference = renter) & 0.017 & & 0.264 \\
\hline Years Living in the Neighborhood & -0.017 & & 0.015 \\
\hline Gender (Male) & -0.477 & * & 0.212 \\
\hline Age & -0.003 & & 0.011 \\
\hline Distance from supermarket (blocks) & -0.066 & * & 0.021 \\
\hline Constant & -0.434 & & 0.484 \\
\hline Nagelkerke $R^{2}$ & 0.271 & & \\
\hline
\end{tabular}

\footnotetext{
${ }^{*}=p<0.05 ;{ }^{* *}=p<0.01$.
} 
My findings also contribute to the retail gentrification literature by showing that the racial differences are not limited to stores selling non-essential goods (e.g., restaurants and boutiques), but also include those that sell basic goods. Some American scholars help explain these racial boundaries by arguing that alternative food practices in the U.S. are dominated by whites, associated with whiteness, and are perpetuated by white privilege (Slocom, 2007; Guthman, 2008; Alkon, 2012). Although white businesses, workers, and customers may assume a position of "colorblindness" when discussing such topics as organic food, local produce, and "healthy living," these scholars argue that racial minorities often feel excluded.

\section{The Social Class Hypothesis: Education, Not Ownership}

One dimension of social class-education-also is important. The odds that someone with a college degree shops there weekly are over three times as high as those without a degree. Among the different education categories, those with a college degree or an advanced degree are about twice as likely to shop there weekly as those with some college/two-year associate's degree (38\%) or a high school degree (31\%) and about five times as likely as those with less than a high school degree $(17 \%)$. The weekly usage of those with a college degree or higher (67\%), however, is far higher than all of these less educated groups. These findings support the work of previous researchers who find that the college-educated middle class are more likely to have a taste for "mind-body" products and services such as yoga, alternative medicine, and organic food (Bridge \& Dowling, 2001; Su \& Li, 2011). Doel \& Segrott (2003), in addition, suggest that "mind-body" clients are well informed about health issues, which suggests that those with more education tend to know more about nutrition and about the health and environmental impacts of highly processed, industrially produced, and nonlocal food.

However, another dimension of social class-tenure status -is not significantly associated with shopping at the new supermarket; renters and homeowners have similar usage patterns. Future research should examine whether income-a dimension of social class that is not available in this data set-is correlated with usage. The higher prices of many of New Seasons products, in comparison to more mainstream supermarkets in adjacent neighborhoods, suggests that those with more income would be more likely to shop there regularly.

Surprisingly, once race and social class are taken into account in the regression analysis, there are no significant differences in weekly usage between newcomers and longtime residents. This suggests that the typical "newcomer" characteristics in racially/ethnically diverse, gentrifying neighborhoods of being white and college educated are the most salient, and that food shopping routines that longtime residents have established over the years are not as important.

Among the control variables, women and those living closer to the store are more likely to shop there weekly, but age is not significant.

\section{Discussion}

Food deserts can be detrimental to neighborhood residents' health. So it would seem intuitive that the opening of a supermarket, especially one that emphasizes healthful food and life- style, would result in positive health effects. You would get no argument from "urban regeneration" advocates, who espouse the virtues of middle-class residents moving into previously poor neighborhoods (i.e., gentrification). These virtues include a larger retail sector, including supermarkets, from which they assume all residents benefit. But is their assumption accurate? Certainly urban scholars who study retail gentrification would be skeptical, arguing that new retail cater largely to newcomers and marginalize longtime residents, especially the poor and minorities. But their skepticism is based largely on analyses of non-essential retail such as boutique clothing stores and bars. Further, their qualitative approaches, although providing rich detail, do not systematically measure shopping behavior.

My study examines supermarket shopping behavior in a racially and socioeconomically diverse neighborhood in Portland that is in the process of gentrifying. Does the opening of a supermarket eliminate the food desert or does it instead create a food mirage, whereby minority and lower-class residents do not find it to be a viable option for their regular food shopping? Using probability sampling and regression analysis, my survey of 425 randomly selected individuals supports the skepticism of retail gentrification scholars. Although most residents have shopped at the new supermarket at least once in the past twelve months, only about half of them use it regularly. White and college-educated residents—characteristics closely aligned with gentrifiers-are much more likely to shop there weekly than are minority and less educated residents. These findings support the work of Breyers \& Voss-Andreae (2013) who find that none of Portland's racially diverse and gentrifying neighborhoods are food deserts, but rather food mirages.

\section{Conclusion}

Future research should examine the reasons for these racial and social class differences in usage. Sullivan \& Shaw (2011) use in-depth interviews to understand residents' opinions of new retail in this neighborhood and find significant symbolic boundaries based on race: blacks feel excluded and are resentful of the new retail, which includes a substantial number of mind-body businesses that are similar to New Seasons. In addition, the work of Bridge \& Dowling (2001) and Su \& Li (2011) in other cities suggests that there may be symbolic boundaries based on social class. Clearly New Seasons attempts to appeal to a particular "mind-body" facet of the middle class - through its food and non-food products and its other retail semiotics -but it also makes some effort to attract other kinds of neighborhood residents. Future research needs to explore further the salience of social class by examining which facet-its cultural or economic dimension-is most salient. Do less educated and minority residents shop there, less mostly due to higher prices, symbolic boundaries, and/or some other reasons?

It is clear that the mind-body lifestyle espoused by much of the new retail in the Alberta neighborhood, including the New Seasons supermarket, continues to grow in Portland (Gunderson, 2013); in fact, it is a trend that is likely to increase in other cities throughout the US and the world. And with a growing number of racially and ethnically diverse neighborhoods in cities throughout the world, due to increasing immigration (Pemberton, 2008; Bretherton \& Pleace, 2011), the challenge for supermarkets is to avoid creating a "food mirage" by constructing spaces that, on the one hand, promote healthy living and environmental sustainability and, on the other hand, in- 
crease food access to a range of racial, ethnic, and socioeconomic groups.

\section{REFERENCES}

Alkon, A. (2012). Black, white, and green. Athens, GA: University of Georgia Press.

Alwitt, L. F., \& Donley, T. D. (1997). Retail stores in poor urban neighborhoods. The Journal of Consumer Affairs, 31, 139-164. http://dx.doi.org/10.1111/j.1745-6606.1997.tb00830.x

Baarts, C., \& Pederson, I. K. (2009). Derivative benefits: Exploring the body through complementary and alternative medicine. Sociology of Health and Illness, 31, 719-733.

http://dx.doi.org/10.1111/j.1467-9566.2009.01163.x

Beaven, S. (2005). Joe Benjamin, Sr.: Hosting good times amid changing times. The Oregonian, A1, Portland, OR.

Breyer, B., \& Voss-Andreae, A. (2013). Food mirages. Health \& Place, 24, 131-139. http://dx.doi.org/10.1016/j.healthplace.2013.07.008

Bretherton, J., \& Pleace N. (2011). A difficult mix. Urban Studies, 48, 3433-3447. http://dx.doi.org/10.1177/0042098010396233

Bridge, G., \& Dowling, R. (2001). Microgeographies of retailing and gentrification. Australian Geographer, 32, 93-107. http://dx.doi.org/10.1080/00049180020036259

Burk, B. (2006). A decade of change on Alberta. The Portland Observer, $1,11$.

Byrne, J. P. (2003). Two cheers for gentrification. Howard Law Journal, 46, 405-432.

Coveney, J., \& O’Dwyer, L. A. (2009). Effects of mobility and location on food access. Health \& Place, 15, 45-55.

http://dx.doi.org/10.1016/j.healthplace.2008.01.010

Deener, A. (2007). Commerce as the structure and symbol of neighborhood life. City \& Community, 6, 291-314. http://dx.doi.org/10.1111/j.1540-6040.2007.00229.x

The Diggable City Project Team (2005). Thediggable city. Portland, OR: Portland State University, Nohad A. Toulan School of Urban Studies and Planning.

Doel, M. A., \& Segrott, J. (2003). Self, health, and gender: Complementary and alternative medicine in the British mass media. Gender, Place and Culture, 10, 131-144.

http://dx.doi.org/10.1080/0966369032000079523

Duany, A. (2001). Three cheers for gentrification. The American Enterprise, 15, 36-39.

Everett, M. (2011). Practicing anthropology on a community-based public health coalition. Annals of Anthropological Practice, 35, 1026. http://dx.doi.org/10.1111/j.2153-9588.2011.01079.x

Fitzgibbon, J. (2006). Reflections of Hurricane Katrina. The Oregonian, Portland.

Freeman, L. (2006). There goes the 'hood. Philadelphia: Temple University Press.

Gonzalez, S., \& Waley, P. (2012). Traditional retail markets. Antipode, 45, 965-983. http://dx.doi.org/10.1111/j.1467-8330.2012.01040.x

Grogan, P. S., \& Proscio, T. (2000). Comeback cities. Boulder, CO: Westview Press.

Gunderson, L. (2013). Lisa Sedlar's new Green Zebra Grocery will open in Woodstock and Kenton. The Oregonian, Portland, OR.

Guthman, J. (2008). Bringing good food to others. Cultural Geographies, 15, 431-447. http://dx.doi.org/10.1177/1474474008094315

Guy, C. M., \& David, G. (2004). Measuring physical access to "healthy foods" in areas of social deprivation: A case study of Cardiff. International Journal of Consumer Studies, 28, 222-234. http://dx.doi.org/10.1111/j.1470-6431.2003.00340.x

Jun, M. J. (2004). The effects of Portland's urban growth boundary on urban development patterns and commuting. Urban Studies, 41, 13331348. http://dx.doi.org/10.1080/0042098042000214824

Hallsworth, A., \& Wood, A. (1986). Welfare and retail accessibility. Area, 18, 291-298.

Kennedy, M., \& Leonard, P. (2001). Dealing with neighborhood change. Washington D C: The Brookings Institution.

Killingsworth, R. E., \& Lamming, J. (2001). Development and public health. Urban Land, 12-17.

Larson, N. I., Story, M. T., \& Nelson, M. C. (2009). Neighborhood environments: Disparities in access to healthy foods in the US. American Journal of Preventative Medicine, 36, 74-81. http://dx.doi.org/10.1016/j.amepre.2008.09.025

Lloyd, R. (2006). Neo-bohemia. New York: Routledge.

Maly, M. (2005). Beyond segregation. Philadelphia: Temple University Press.

Maurrasse, D. J. (2006). Listening to Harlem. New York: Routledge.

Mirk, S. (2012). It's not about the bikes. Portland Mercury, Portland, OR.

Morland, K. B., Wing, S., Diez Roux, A., \& Poole, C. (2002). Neighborhood characteristics associated with the location of food stores and food service places. American Journal of Preventative Medicine, 22, 23-29. http://dx.doi.org/10.1016/S0749-3797(01)00403-2

Paez, A., Mercado, R. G., Farber, S., Morency, C. \& Roorda, M. (2010). Relative accessibility deprivation indicators for urban settings. Urban Studies, 47, 1415-1438. http://dx.doi.org/10.1177/0042098009353626

Pascual-Molinas, N., \& Ribera-Fumaz, R. (2009). Retail gentrification in Ciutat Vella, Barcelona. In L. Porter, \& K. Shaw (Eds.), Whose urban renaissance (pp. 180-190). London: Routledge.

Patch, J. (2008). Ladies and gentrification. Research in Urban Sociology, 9, 103-126. http://dx.doi.org/10.1016/S1047-0042(07)00005-0

Pemberton, S. (2008). Cities and labour immigration. Urban Studies, 45, 992-995. http://dx.doi.org/10.1177/00420980080450041103

Rutland, T., \& Aylett, A. (2008). The work of policy. Environment and Planning D, 26, 627-646. http://dx.doi.org/10.1068/d6907

Schmidt, B. (2012). Subsidizing segregation. The Oregonian, Portland. Scott, A. (2012). By the grace of God. Portland Monthly, Portland.

Shaw, K., \& Porter, L. (2009). Introduction. In L. Porter, \& K. Shaw (Eds.), Whose urban renaissance (pp. 1-19)? London: Routledge.

Short, A., Guthman, J., \& Raskin, S. (2007). Food deserts, oases, or mirages? Journal of Planning Education and Research, 26, 352-364. http://dx.doi.org/10.1177/0739456X06297795

Slocum, R. (2007). Whiteness, space, and alternative food practice. Geoforum, 38, 520-533. http://dx.doi.org/10.1016/j.geoforum.2006.10.006

Small, M. L., \& McDermott, M. (2006). The presence of organizational resources in poor urban neighborhoods. Social Forces, 84, 16971723. http://dx.doi.org/10.1353/sof.2006.0067

Sparkes, A. L., Bania, N., \& Leete, L. (2011). Comparative approaches to measuring food access in urban areas: The case of Portland, Oregon. Urban Studies, 48, 1715-1737. http://dx.doi.org/10.1177/0042098010375994

Su, D., \& Li, L. (2011). Trends in the use of complementary and alternative medicine in the United States: 2002-2007. Journal of Health Care for the Poor and Underserved, 22, 296-310.

Sullivan, D. M., \& Shaw, S. C. (2011). Retail gentrification and race. Urban Affairs Review, 47, 403-422.

Svoboda, E. (2008). Portland: No. 1-Greenest city in America. Popular Science.

Walker, R. E., Keane, C. R., \& Burke, J. G. (2010). Disparities and access to healthy food in the United States. Health \& Place, 16, 876884. http://dx.doi.org/10.1016/j.healthplace.2010.04.013

White, M. (2007.) Food access and obesity. Obesity Reviews, 8, 99-107. http://dx.doi.org/10.1111/j.1467-789X.2007.00327.x

White, M., Bunting J., Williams, E., Raybould, S., Adamson, A., \& Mathers, J. (2004). Do food deserts exist? Food Standards Agency, New Castle University.

Wrigley, N. (2002). Food deserts in British cities. Urban Studies, 39, 2029-2114. http://dx.doi.org/10.1080/0042098022000011344

Zellmer, J. (2010). Portland and elite cities, The Economist.

Zukin, S. (2008).Consuming authenticity. Cultural Studies, 22, 724-748. http://dx.doi.org/10.1080/09502380802245985

Zukin, S., Trujillo, V., Frase, P., Jackson, D., Recuber, T., \& Walker, A. (2009). New retail capital and neighborhood change. City \& Community, 8, 47-64. http://dx.doi.org/10.1111/j.1540-6040.2009.01269.x 